\title{
KESALAHAN BERBAHASA BIDANG FONOLOGI LOWONGAN KERJA SOLORAYA DI INSTAGRAM
}

\section{PHONOLOGICAL ERROR OF JOB VACANCY SOLORAYA ON INSTAGRAM}

\author{
Muthi'ah Ahmad, Purwanti, Fitria Nur Agustin \\ Universitas Islam Negeri Raden Mas Said Surakarta \\ Jalan Pandawa, Dusun IV, Pucangan, Kec. Kartasura, Kabupaten Sukoharjo, \\ Jawa Tengah, Kode Pos 57168 \\ Ponsel: 081327315918; Pos-el: purwanti070517@gmail.com
}

\begin{abstract}
Abstrak
Informasi lowongan pekerjaan yang tersebar di kalangan masyarakat luas ternyata terdapat kesalahan berbahasa. Segala informasi yang diunggah ke media sosial tidak memperhatikan kaidah kebahasaan. Hal ini tidak berlaku pada informasi lowongan kerja yang notabene menggunakan ragam bahasa tulis resmi. Oleh karena itu, penelitian ini bertujuan mengetahui susunan kesalahan fonologi pada informasi lowongan kerja di instagram serta mengetahui faktor penyebabnya. Pengumpulan data pada penelitian ini menggunakan pendekatan deskriptif kualitatif dengan motode simak bebas libat cakap, data berbentuk ungkapan kata informasi yang diobservasi oleh peneliti sehingga mendapatkan hasil yang sesuai. Hasil penelitian ini dari 10 sumber data ditemukan 59 data yang terdapat kesalahan berbahasa bidang fonologi berupa (1) perubahan bunyi 23 data; (2) penghilangan bunyi 12 data; dan (3) penambahan bunyi 24 data. Kesalahan tersebut berupa perubahan bunyi seperti [a] menjadi [e], perubahan bunyi [a] menjadi [o], perubahan bunyi [e] menjadi [a] dst. penghilangan bunyi $[\mathrm{n}],[\mathrm{e}],[\mathrm{o}],[\mathrm{r}] \mathrm{dan}$ penambahan bunyi $[\mathrm{h}],[\mathrm{l}],[\mathrm{h}],[\mathrm{t}],[\mathrm{n}],[\mathrm{a}],[\mathrm{o}],[\mathrm{u}],[\mathrm{i}],[\mathrm{d}]$. Hal ini dilatarbelakangi oleh adanya pengaruh bahasa asing atau penyerapan unsur serapan, kurangnya kompetensi berbahasa Indonesia atau ketidaktahuan seorang penutur, dan pembiasaan di lingkungan.
\end{abstract}

Kata-kata kunci: kesalahan fonologi; lowongan kerja; Soloraya; instagram 


\begin{abstract}
Information on the job vacancy that spread in the society obvious language error. All of the information that uploaded in social media do not pay attention to grammar. This case do not apply in job vacancy information that used formal written language. Therefore, this research aims to know phonology error structure in the job vacancy information on Instagram and the factors that affect it. The data collection in the research used a qualitative descriptive approach with simak bebas libat cakap method, the form of data was expression of information that observed by the researcher so that researcher got the result as predicted. The result from the 10 data sources was found that there was 59 data with phonology error as following (1) 23 data sound changes; (2) 12 data sound deletion; and (3) 24 data sound addition. The errors can be in the form of sound changes like [a] become [e], shound changes [a] become [o], sound changes [e] become [a], etc. sound deletion of [n], [e], [o], [r] and sound addition of $[h],[l],[h],[t],[n],[a],[o],[u],[i],[d]$. This errors was caused by foreign language affection or absorption, the lack of Indonesian language competence or the ignorance of the speaker, and the habitual.
\end{abstract}

Keywords: phonology error; job vacancy; Soloraya; instagram

\section{Pendahuluan}

Krisis ekonomi yang melanda dunia seiring dengan adanya peningkatan perkembangan ilmu pengetahuan dan teknologi menjadi salah satu perhatian penting, khususnya bangsa Indonesia yang termasuk ke dalam kategori negara berkembang. Negara berkembang pasti masih memiliki ketergantungan dengan negara-negara lain. Oleh karena itu, negara berkembang mengekspor barang untuk dijual kembali sebagai nilai tambah bagi pertumbuhan perekonomian negara berkembang.

Faktor kemiskinan yang terjadi di negara berkembang menjadi salah satu pendorong semangat untuk bekerja demi pemenuhan kebutuhan hidup sehari-hari. Semakin banyaknya jumlah penduduk maka kebutuhan pekerjaan juga pasti meningkat. Adanya informasi lowongan kerja yang beredar di berbagai media dapat dijadikan peluang untuk memanfaatkan kesempatan dengan sebaik-baiknya. Sebab, informasi merupakan sumber pengolahan data yang dapat memberikan nilai dan pemahaman bagi penggunanya (Maisaroh et al., 2019: 112). Seluruh bidang pekerjaan pasti membutuhkan sistem informasi untuk memajukan sektor pembangunan di dalam segala aspek kebutuhan hidup manusia. Semua bidang pembangunan beserta dimensinya membutuhkan informasi yang relevan sebagai data pendukung dalam mengupayakan pembangunan agar bisa mencapai hasil yang optimal (Sutabri, 2012: 37). Beberapa sistem informasi bisa 
menggunakan alat perangkat keras dan perangkat lunak yang bisa diakses dengan teknologi informasi. Namun dalam informasi tidak lepas dengan penggunaan ragam bahasa baik bahasa lisan dan tulis.

Di dalam ragam bahasa lisan ditinjau dari segi perpaduan antara sarana dan suasana dapat menjadi ragam lisan resmi dan ragam lisan tidak resmi. Begitu juga penggunaan ragam bahasa tulis, ragam tulis resmi, dan ragam tulis tidak resmi.Informasi lowongan pekerjaan yang telah tersebar di kalangan masyarakat luas masih terdapat kesalahan berbahasa tulis. Penggunaan bahasa Indonesia yang baik dan benar seharusnya dapat berlaku di ranah media.

Kedudukan bahasa Indonesia sebagai bahasa negara bisa ditinjau dari empat segi. Pertama, bahasa resmi negara. Kedua, bahasa pengantar resmi di lembaga-lembaga pendidikan. Ketiga, bahasa resmi dalam perhubungan nasional, baik untuk kepentingan perencanaan dan pelaksanaan pembangunan serta untuk kepentingan pemerintahan. Keempat, bahasa resmi di dalam kebudayaan dan pemanfaatan ilmu pengetahuan dan teknologi modern (Setyawati, 2013: 1).
Hal ini mengacu pada Peraturan Presiden Republik Indonesia No. 63 Tahun 2019 pasal 40 ayat 1 menyatakan bahwa bahasa Indonesia wajib digunakan dalam fasilitas umum, spanduk, rambu umum, penunjuk jalan, dan alat informasi lain yang merupakan pelayanan umum.

Peraturan Presiden Republik Indonesia No. 63 Tahun 2019 dapat berlaku juga pada informasi lowongan kerja di Instagram yang ditinjau dalam ragam bahasa tulis resmi. Pada umumnya, segala informasi yang diunggah ke media sosial tidak memperhatikan kaidah kebahasaan. Hal ini tidak berlaku pada informasi lowongan kerja yang notabene menggunakan ragam bahasa tulis resmi. Sebab, lowongan pekerjaan tidak hanya bersumber dariindustri masyarakat. Lowongan pekerjaan juga bersumber pada instansi-instansi resmi yang sudah disahkan oleh pimpinan instansi berlatar belakang pendidikan tinggi.

Hal ini sejalan dengan hasil penelitian yang dilakukan oleh Akmaluddin (2018: 2) yang menyatakan bahwa dalam penggunaan bahasa Indonesia sebagai bahasa negara ada aturan khusus yang mengikat, sudah seharusnya menjadi kewajiban lembaga 
Kesalahan Berbahasa Bidang ...

negara untuk selalu menggunakan

perundang-undangan yang menegaskan

kaidah bahasa Indonesia khususnya

pentingnya penggunaan bahasa

dalam bahasa tulisan.

Instansi-instansi resmi termasuk ke dalam situasi atau suasana formal hendaknya menggunakan istilah ragam bahasa baku. Selain dalam situasi formal, ragam baku juga digunakan dalam surat menyurat resmi, perundangundangan negara, administrasi pemerintahan, dan karya-karya ilmiah (Nurdijan, 2018: 23). Surat menyurat yang bersifat resmi dalam proses pembuatannya harus menggunakan kaidah kebahasaan yang benar. Sebab, surat merupakan sarana komunikasi sebagai salah satu informasi yang digunakan antara pengirim dan penerima dalam lingkup perseorangan, lembaga, ataupun instansi (Ridho, 2020: 3-4). Hal tersebut juga dapat diberlakukan dalam informasi lowongan kerja dikarenakan sebuah informasi pekerjaan sudah melalui persetujuan dari lembaga terkait, baik lembaga kerja pemerintah maupun swasta. Oleh sebab itu, informasi lowongan kerja juga harus menerapkan kaidah kebahasaan yang benar. Hal ini sependapat dengan hasil penelitian yang dilakukan oleh Akmaluddin (2018: 4) yang menyatakan bahwa sudah ada aturan-aturan Indonesia yang baik dan benar dalam pelayanan administrasi publik dan forum resmi kenegaraan.

Kesalahan berbahasa dapat dikaitkan dengan kegiatan berbahasa, seperti menulis. Kesalahan penggunaan ragam bahasa tulis sering terjadi pada bidang fonologi. Kesalahan berbahasa yang tidak sesuai dengan kaidah kebahasaan dapat terjadi akibat adanya intereferensi bahasa dan pelafalan alat ucap manusia yang dapat berdampak pada ragam lisan dan ragam tulis.

Kesalahan berbahasa pada ragam tulis informasi lowongan kerja tidak bisa dianggap sepele dan dibiarkan menjadi hal biasa dilakukan dan membudaya di kalangan masyarakat. Karena bahasa merupakan jati diri bangsa. Hal ini seharusnya bisa menjadi fokus perhatian bagi masyarakat, khususnya penutur bahasa Indonesia agar melakukan perbaikan terhadap kesalahan berbahasa ragam tulisan untuk menghindari munculnya sikapsikap negatif yang ada di lingkungan masyarakat. Hal ini sejalan dengan hasil penelitian yang dilakukan oleh Akmaluddin yaitu tentang kesalahan berbahasa ragam tulis yang menjadi 
problematika bahasa indonesia kekinian (Akmaluddin, 2016: 81). Penelitian tersebut menyatakan bahwa pengetahuan masyarakat terkait tata bahasa Indonesia yang baik dan benar masih minim. Sehingga menyebabkan landasan berpikir yang menyimpang terhadap penggunaan bahasa Indonesiasebagai salah satu sikap negatif berbahasa ditandai dengan adanya kecenderungan menggunakan struktur bahasa dan kosakata asing. Oleh sebab itu, adanya penelitian ini bertujuan untuk (1) mengetahui susunan kesalahan fonologi pada informasi lowongan kerja di instagram. (2) Mengetahui faktor-faktor yang melatarbelakangi terjadinya kesalahan berbahasa pada informasi lowongan kerja di instagram. (3) Memberikan sumbangan informasi kaidah bahasa Indonesia.

Ketepatan berbahasa dalam informasi lowongan kerja saat ini masih diabaikan. Sedangkan informasi tersebut, dinaungi oleh lembaga resmi yang tentunya orang-orang yang berada di dalamnya adalah orang cendekia sehingga hal tersebut tidak mencerminkan sebagaimana mestinya. Kesalahan tersebut hingga diikuti lembaga lain dan menjadi kebiasaan hingga penulisan bahasa yang sesuai kaidah menjadi terabaikan. Asumsi masyarakat adalah analisis kesalahan berbahasa dalam ragam tulisan sangat bersangkut paut pada bidang akademik. Setiap satuan lembaga kependidikan tentu memiliki kurikulum mata pelajaran bahasa Indonesia yang berlaku. Kurikulum mata pelajaran bahasa Indonesia memuat poin terkait pembelajaran penggunaan bahasa Indonesia yang baik dan benar. Pandangan masyarakat sebagai lulusan dari satuan pendidikan tentu harus memiliki kompetensi yang mumpuni di dalam mengolah kebahasaan, khususnya dalam ragam tulis sehingga kesalahan tidak terulang kembali secara terusmenerus dilakukan. Sehingga kesadaran masyarakat akan pentingnya sikap positif dalam berbahasa Indonesia yang baik dan benar perlu diperbaiki dan dikembangkan untuk menjaga kelestarian bahasa di lingkup masyarakat.

\section{Landasan Teori}

Kesalahan berbahasa merupakan penyimpangan bentuk-bentuk ujaran berbagai unit kebahasaan baik kata, frasa, kalimat, paragraf yang menyimpang dari ketatabahasaan 
Indonesia, serta pemakaian ejaan, dan tanda baca yang telah diatur di dalam Pedoman Umum Ejaan Bahasa Indonesia (Ningrum, Purnami, \& Lestari, 2021: 100).

Fonologi dapat diartikan sebagai satuan sistem linguistik yang menelaah tentang runtunan bunyi-bunyi bahasa secara mendetail. Runtunan bunyi-bunyi bahasa tersebut dapat diperoleh dari alat indra pengucapan manusia dan dapat dianalisis berdasarkan tingkat-tingkat kesatuannya (Chaer, 2013: 1). Pengucapan pada setiap lambang bunyi bahasa yang dilakukan oleh pemakai bahasa Indonesia, tidak boleh dilafalkan menurut kemauan masing-masing. Pematuhan kaidah bahasa Indonesia bisa diterapkan jika ingin mendapatkan penilaian yang baik terhadap ucapan bahasa Indonesia.

Kesalahan berbahasa Indonesia dalam bidang fonologi bisa terjadi secara lisan maupun tertulis. Sebab, saat kesalahan pelafalan dituliskan bisa terjadi juga kesalahan berbahasa dalam ragam tulis (Setyawati, 2013: 23). Beberapa gambaran kesalahan penulisan, seperti perubahan bunyi karena penulisan bunyi-bunyi tidak diucapkan sesuai kaidah, penghilangan bunyi karena pemakai bahasa sering menghilangkan bunyi tertentu pada sebuah kata sehingga penulisan menjadi salah, dan penambahan bunyi karena pemakai bahasa menambahkan bunyi tertentu pada kata-kata yang diucapkan.

Menurut (Mantasiah \& Yusri, 2020: 15) jenis kesalahan berbahasa tataran fonologi yaitu (1) kesalahan pengucapan bunyi. Kesalahan ini terjadi karena salah dalam pengucapan bunyibunyi bahasa. (2) Kesalahan penghilangan bunyi. Kesalahan ini dikarenakan adanya bunyi yang tidak diucapkan atau dihilangkan sehingga tidak diucapkan secara lengkap. (3) Kesalahan penambahan bunyi yaitu karena adanya penambahan bunyi di luar bunyi bahasa yang seharusnya diucapkan, dan yang terakhir yaitu (4) kesalahan dalam meletakkan jeda pada frasa atau kata.

Kaidah bahasa merupakan kriteria yang digunakan dalam melihat penggunaan bahasa yang benar. Kaidah tersebut salah satunya meliputi aspek tata bunyi (fonologi). Pada aspek tata bunyi misalnya bunyi [f], [v] dan [z]. Misalnya, kata-kata yang benar adalah aktif, fajar, vitamin, devaluasi, izin bukan kata aktip, pajar, pitamin, depaluasi, ijin. Selain itu adalah masalah lafal yang termasuk tata bunyi. 
Pelafalan yang benar misalnya kata kompleks, korps, transmigrasi, ekspor bukan komplek, korp, tranmigrasi, dan ekspot (Sugono, 2009: 22). Jika dicermati kesalahan tersebut terjadi adanya perubahan bunyi dan penghilangan bunyi.

Berdasarkan ulasan di atas, dapat disimpulkan bahwa fonologi sebagai satuan sistem linguistik yang menelaah tentang runtutan bunyi-bunyi bahasa secara mendetail. Khususnya pada bunyi-bunyi bahasa yang dihasilkan oleh alat indra pengucapan manusia. Kesalahan bidang fonologi dalam ejaan fonetis terjadi secara tulis.Kesalahan ini dapat berupa perubahan bunyi, penghilangan bunyi maupun penambahan bunyi.

Media sosial sangat populer salah satunya yaitu Instagram, instagram merupakan media yang lebih terfokus pada fitur pada gambar, video dan gambar bermuatan tulisan. Gambar dan video yang sering diunggah di akun Instagram dapat juga disertai dengan status (caption) yang menjelaskan atau memberi keterangan gambar dan video yang diunggah. (Ningrum, Purnami, \& Lestari, 2021: 100).

\section{Metode Penelitian}

Penelitian ini digunakan untuk mengungkapkan fenomena yang terjadi seputar kesalahan berbahasa dalam penulisan informasi lowongan kerja di instagram. Penelitian ini menggunakan pendekatan deskriptif kualitatif. Deskriptif kualitatif merupakan penelitian yang bersifat naratif dan lebih memfokuskan pada pendalaman pemahaman peneliti terhadap suatu permasalahan yang sedang dikaji dengan per tahapan (Siyoto, 2015: 28). Data yang muncul di dalam penelitian kualitatif ini berbentuk ungkapan kata informasi yang diobservasi oleh peneliti sehingga mendapatkan hasil yang sesuai. Adapun sumber data dalam penelitian ini adalah berupa dokumen informasi lowongan kerja tahun $2021 \mathrm{di}$ instagram dengan jumlah 10 akun yang bermuatan ragam tulis resmi.

Tahap pengumpulan data, peneliti menggunakan motode simak bebas libat cakap yaitudengan cara peneliti melakukan pengamatan terhadap penggunaan bahasa oleh para informan (Mahsun, 2012: 93). Pada tahap ini peneliti mengamati penggunaan bahasa yang terdapat pada kumpulan informasi lowongan kerja di instagram tahun 2021. Instrumen pengumpulan data 
adalah pamflet lowongan kerja. Prosedur pengumpulan data dengan menemukan objek kesalahan fonologi pada informasi lowongan kerja berdasarkan golongan yang sesuai.

Analisis data dilakukan denganmetode padan intralingual yaitudengan menghubung-bandingkan unsur-unsur yang berada dalam bahasa baik dalam satu bahasa maupun bahasa beberapa bahasa. Pada tahap ini peneliti memilah data yang diperlukan dengan mengelompokkan data, dengan menyamakan data-data yang sama dan membedakan data yang beda. Tujuan dari teknik ini adalah untuk mengumpulkan data yang berhubungan dengan penelitian. Setelah dicatat, data yang sudah ditemukan diklasifikasikan data berdasarkan golongan yang sesuai. Kemudian dideskripsikan bentuk kesalahannya dan memberikan pembetulan data yang diperoleh dari analisis.

Hasil analisis data disajikan dengan cara perumusan yang menggunakan kata-kata biasa disertai dengan tanda kurung siku ([]). Tanda ini merupakan satuan fonetis digunakan untuk melambangkan bunyi tertentu yang bukan berstatus fonem dalam bidang fonologi.

\section{Pembahasan}

Kesalahan fonologi berbahasa dapat terjadi pada perubahan fonem, penambahan bunyi, dan penghilangan bunyi. Kesalahan fonologi pada perubahan bunyi dapat terjadi di awal, di tengah, dan di akhir. Bentuk kesalahan fonologi yang terdapat pada informasi lowongan kerja soloraya di Instagram yang terdiri atas 14 perubahan bunyi, 4 penghilangan bunyi, dan 10 penambahan bunyi.

\subsection{Perubahan Bunyi}

Pada data 1a-15a terdapat kesalahan bunyi bahasa yang berbedabeda yang terdiri atas perubahan bunyi [a] menjadi [e], penulisan atau [a] menjadi [o], perubahan bunyi [e] menjadi [a] perubahan bunyi [e] menjadi [i], perubahan bunyi [f] menjadi [v], bunyi [i] menjadi [e], perubahan bunyi [i] menjadi [y], perubahan bunyi [j] menjadi [y], perubahan bunyi [k] menjadi [c] perubahan bunyi $[\mathrm{k}]$ menjadi [q], perubahan bunyi $[\mathrm{k}]$ menjadi $[\mathrm{x}]$, perubahan bunyi[g] menjadi [j], perubahan bunyi[p] menjadi [f], perubahan bunyi [s] menjadi [c], perubahan bunyi [z] menjadi [s].

1.a. akte $\rightarrow$ akta

1.b. familier $\rightarrow$ familiar 
1.c. kenderaan $\rightarrow$ kendaraan

1.d. leptop $\rightarrow$ laptop

1.e. terget $\rightarrow$ target

2.a. sholat $\rightarrow$ salat

3.a. tauladan $\rightarrow$ teladan

4.a. shalih $\rightarrow$ saleh

5.a. aktiv $\rightarrow$ aktif

5.b. kreatifitas $\rightarrow$ kreativitas

5.c. sertivikat $\rightarrow$ sertifikat

6.a. team $\rightarrow$ tim

7.a. survey $\rightarrow$ survei

8.a. subyek $\rightarrow$ subjek

9.a. artistic $\rightarrow$ artistik

9.b. copy $\rightarrow$ kopi

9. c. subject $\rightarrow$ subjek

10.a. bertaqwa $\rightarrow$ bertakwa

11.a. maximal $\rightarrow$ maksimal

12.a. enerjik $\rightarrow$ energik

13.a. faham $\rightarrow$ paham

14.a. social $\rightarrow$ sosial

15.a. ijasah $\rightarrow$ ijazah

Jika dicermati pada data 1a-15a terdapat kesalahan penulisan bunyi bahasa yang berbeda-beda. Pada data 1a-1e, ditemukan penulisan yang berupa perubahan bunyi [a] menjadi [e]. Pada data 2a, ditemukan perubahan bunyi [a] menjadi [o]. Pada data 3a, ditemukan perubahan bunyi[e] menjadi [a]. Pada data $4 \mathrm{a}$, ditemukan perubahan bunyi [e] menjadi [i]. Pada data 5a-5c, ditemukan perubahan bunyi [f] menjadi [v]. Pada data $6 a$, ditemukan perubahan bunyi [i] menjadi [e]. Pada data 7a, ditemukan perubahan bunyi [i] menjadi [y]. Pada data 8a, ditemukan perubahan bunyi [j] menjadi [y]. Pada data 9a-9c, ditemukan perubahan bunyi [k] menjadi [c]. Pada data 10a, ditemukan perubahan bunyi [k] menjadi [q]. Pada data 11a, ditemukan perubahan bunyi $[\mathrm{k}]$ menjadi [x]. Pada data 12a, ditemukan perubahan bunyi [g] menjadi [j]. Pada data 13a, ditemukan perubahan bunyi [p] menjadi [f]. Pada data 14a, ditemukan perubahan bunyi [s] menjadi [c]. Pada data 15a, ditemukan perubahan bunyi [z] menjadi [s].

\subsection{Penghilangan Bunyi}

Pada data 1a-4a terdapat kesalahan penulisan bunyi bahasa yang berbeda-beda. Kesalahan tersebut terdiri atas penghilangan bunyi [n], [e], [o], [r]

1.a. akutansi $\rightarrow$ akuntansi

1.b. degan $\rightarrow$ dengan

2.a. karir $\rightarrow$ karier

2.b ketrampilan $\rightarrow$ keterampilan

2.c. mengooprasikan

mengoperasikan

2.d. sedrajat $\rightarrow$ sederajat

2.e. srabutan $\rightarrow$ serabutan

2.f. telpon $\rightarrow$ telepon

2.g. tlaten $\rightarrow$ telaten

2.h. trakhir $\rightarrow$ terakhir 


\section{3.a. portfolio $\rightarrow$ portofolio}

4.a. transkip $\rightarrow$ transkrip

Jika dicermati pada data 1a-4a terdapat kesalahan penulisan bunyi bahasa yang berbeda-beda. Pada data 1a dan $1 \mathrm{~b}$, ditemukan penghilangan bunyi [n]. Pada data 2a-2h, ditemukan penghilangan bunyi [e]. Pada data 3a, ditemukan penghilangan bunyi [o]. Pada data $4 \mathrm{a}$, ditemukan penghilangan bunyi [r].

\subsection{Penambahan Bunyi}

Pada data 1a-10a terdapat kesalahan penulisan bunyi bahasa yang berbeda-beda. Kesalahan tersebut terdiri atas penambahan bunyi $[\mathrm{h}],[\mathrm{l}],[\mathrm{h}],[\mathrm{t}]$, [n], [a], [o], [u], [i], [d].

1.a. audiens $\rightarrow$ audien

1.b. assuransi $\rightarrow$ asuransi

1.c. issu $\rightarrow$ isu

1.d. pesertas $\rightarrow$ peserta

1.e. professional $\rightarrow$ profesional

1.f. mess $\rightarrow$ mes

2.a. dollar $\rightarrow$ dolar

3.a. dipersilahkan $\rightarrow$ dipersilakan

3.b. menghimbau $\rightarrow$ mengimbau

3.c. rapih $\rightarrow$ rapi

3.d. shalih $\rightarrow$ saleh

4.a. garment $\rightarrow$ garmen

4.b. kontent $\rightarrow$ konten

4.c. subject $\rightarrow$ subjek

4.d. tatto $\rightarrow$ tato 4.e. transport $\rightarrow$ transpor

5.a. innovatif $\rightarrow$ inovatif

6.a. narkotika $\rightarrow$ narkotik

6.b. sholat $\rightarrow$ salat

6.c. team $\rightarrow$ tim

7. a. religious $\rightarrow$ religius

8.a. tauladan $\rightarrow$ teladan

9.a. tekniki $\rightarrow$ teknik

10.a. trend $\rightarrow$ tren

Jika dicermati pada data 1a-10a terdapat kesalahan penulisan bunyi bahasa yang berbeda-beda. Pada data 1a-1f, ditemukan penambahan bunyi [h]. Pada data 2a, ditemukan penambahan bunyi [1]. Pada data 3a-3d, ditemukan penambahan bunyi [h]. Pada data $4 \mathrm{a}-4 \mathrm{e}$, ditemukan penambahan bunyi [t]. Pada data 5a, ditemukan penambahan bunyi [a]. Pada data $6 a-6 c$, ditemukan penambahan bunyi [a]. Pada data 7a, ditemukan penambahan bunyi [o]. Pada data 8a, ditemukan penambahan bunyi [u]. Pada data 9a, ditemukan penambahan bunyi [i]. Pada data 10a, ditemukan penambahan bunyi [d].

Kesalahan berbahasa dalam bidang fonologi dapat ditemukan dalam bentuk pengucapan lisan maupun bahasa tulis. Bahasa tulis atau tulisan memiliki peranan penting dalam memengaruhi pola pikir masnyarakat, 
apakah bunyi yang dituturkan terdapat kesalahan berbahasa bidang fonologi yang pada dasarnya bunyi bahasa memiliki kaitan dengan runtutan bunyi. Sehingga hal ini dapat menimbulkan kesalahan berbahasa bidang fonologi, seperti perubahan bunyi, penghilangan bunyi, dan penambahan bunyi.

\subsection{Faktor Penyebab Kesalahan Berbahasa Bidang Fonologi Pada Informasi Lowongan Kerja \\ Kesalahan berbahasa tataran} fonologi dilatarbelakangi oleh faktor internal dan eksternal (Sikana et al., 2021: 79). Faktor internal dapat dilihat melalui beberapa hal. Pertama, penyerapan unsur serapan yang penulisannya belum sepenuhnya diserap ke dalam bahasa Indonesia secara sempurna dalam arti sesuai dengan kaidah bahasa Indonesia. Penggunaan bahasa yang pada informasi lowongan kerja pertama, dipengaruhi oleh penggunaan bahasa daerah danBahasa asing. Penggunaan bahasa asing dan bahasa daerah yang digunakan dalam penulisan informasi lowongan kerja dapat menimbulkan salah pemahaman pembaca. Akibat adanya penggunaan bahasa daerah dan bahasa asing tersebut dapat menimbulkan pengaruh terhadap pola pikir masyarakat dalam menggunakanbahasa Indonesia yang baik sesuai kaidah bahasa Indonesia. Kesalahan berbahasa dapat dilihat dari penulisan unsur serapan. Unsur serapan bahasa asing ke dalam bahasa Indonesia dapat terjadi pada dua hal, yakni unsur serapan yang belum diserap secara sempurna dan penulisan yang masih menyimpang dari kaidah. Hal ini sepeti pada kasus penyerapan kata "Telephone" yang berasal dari bahasa Inggris yang akan diserap ke dalam bahasa Indonesia namun tulis menjadi "Telpon" yang seharusnya ditulis menjadi "Telepon". Selain itu terjadi pada kasus penyerapan kosakata "Akte" yang berasal dari bahasa Belanda seharusnya ditulis menjadi "Akta" sesuai bahasa baku Indonesia bukan lagi "Akte". Begitu pula dengan kata "Sholat" dari bahasa Arab yang seharusnya ditulis menjadi "Salat". Hal ini menunjukkan bahwa masih terdapat penulisan yang masih menyimpang.

Kedua, kurangnya kompetensi berbahasa Indonesia atau ketidaktahuan seorang penutur. Ketidaktahuan ini membuat penutur menjadi tidak merasa melakukan kesalahan berbahasa bidang fonologi sehingga hal tersebut menjadi pembiasaan dianggap hal wajar dan dianggap benar. Faktor kesalahan berbahasa pada informasi lowongan 
Kesalahan Berbahasa Bidang ...

kerja dapat terjadi karena kurangnya kompetensi berbahasa Indonesia atau ketidaktahuan seorang penutur. Kurangnya kompetensi berbahasa Indonesia dapat terjadi pada seseorang yang belum memahami sistem linguistik. Informasi lowongan kerja tersebut pada dasarnya tidak hanya informasi tulis biasa akan tetapi informasi tersebut dikeluarkan oleh lembaga resmi akan tetapi masih ditemui kesalahan berbahasa bidang fonologi seperti penulisan kata "Fotocopy" atau "Copy" dan penulisan kata "team" ini masih sering ditemui pada sejumlah informasi lowongan kerja. Hal tersebut manandakan bahwa lembaga tersebut tidak mengetahui kaidah yang benar yang seharusnya kata "Fotocopy" ditulis "Fotokopi" dan kata "Team" ditulis menjadi “Tim".

Selanjutnya, faktor eksternal. Ketiga, faktor eksternal yaitu pembiasaan di lingkungan. Pada sejumlah lembaga penyedia informasi lowongan kerja masih sering ditemui kesalahan berbahasa yang serupa sehingga hal ini menjadi pembiasaan yang dianggap benar dan wajar. Kesalahan tersebut dapat mengakibatkan lembaga yang lain mengkuti pola penulisan yang salah.
Oleh sebab itu, penutur atau penyediainformasi lowongan kerja mengikuti kaidah penulisan yang biasa digunakan tanpa harus memeriksa terlebih dahulu apakah penulisan tersebut sudah benar dan telah sesuai kaidah bahasa Indonesia. Hal ini seperti pada penulisan kata "Fotocopy" dan "Ijasah" masih sering dijumpai pada penyedia informasi di sejumlah lembaga penyedia lowongan kerja yang seharusnya kosa kata tersebut ditulis menjadi "Fotokopi" dan "Ijazah". Kebiasan penulisan yang salah tersebut kemudian dapat diikuti lembagalembaga lain yang terjadi berulangkali sehingga hal ini menjadi kebiasaan dan dianggap lumrah.

\section{Penutup}

Berdasarkan uraian pembahasan di atas, dapat disimpulkan bahwa terkait dengan kesalahan berbahasa bidang fonologi pada informasi lowongan kerja Soloraya di instagramdari 10 sumber data ditemukan 59 data yang terdapat kesalahan berbahasa bidang fonologi berupa perubahan bunyi terdapat 23 data. Kesalahan tersebut berupa perubahan bunyi [a] menjadi [e], perubahan bunyi [a] menjadi [o], perubahan bunyi [e] menjadi [a] 


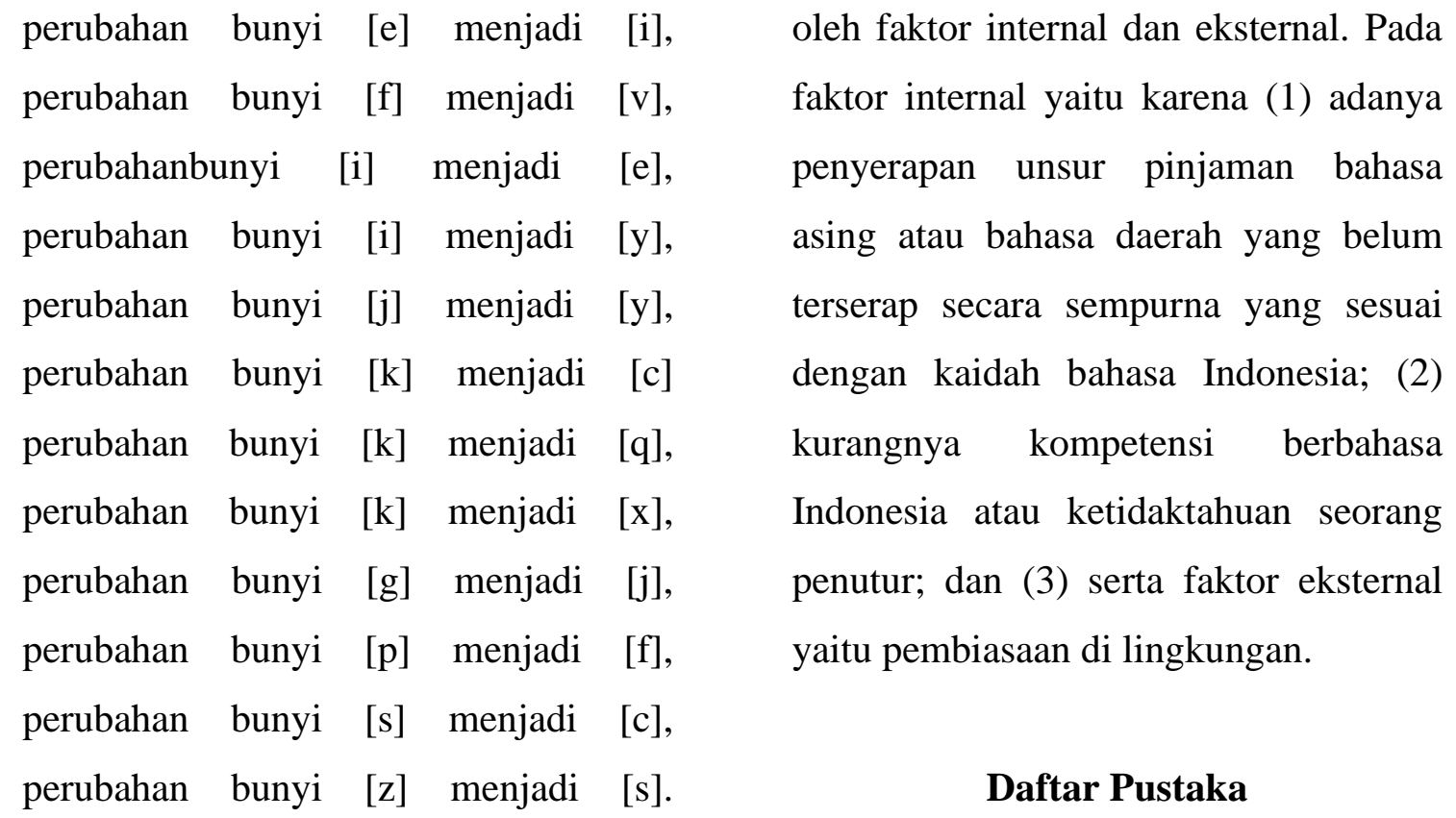

Penghilangan bunyi terdapat 12 data kesalahan tersebut terdiri atas penghilangan bunyi [n], [e], [o], [r] dan penambahan bunyi terdapat 24 data kesalahan tersebut terdiri atas penambahan bunyi $[\mathrm{h}],[1],[\mathrm{h}],[\mathrm{t}],[\mathrm{n}]$, $[\mathrm{a}], \quad[\mathrm{o}], \quad[\mathrm{u}], \quad[\mathrm{i}], \quad[\mathrm{d}]$. Kesalahan berbahasa tataran fonologi tersebut seperti (1) perubahan bunyi, misalnya kata "Survey" yang seharusnya ditulis menjadi "Survei"; (2) penghilangan bunyi, misalnya Ketrampilan" yang seharusnya ditulis menjadi "Keterampilan"; dan (3) penambahan bunyi, misalnya kata "Professional" yang seharusnya ditulis menjadi "Profesional".

Kesalahan berbahasa bidang fonologi pada informasi lowongan kerja soloraya di instagram dilatarbelakangi
Achmad. Abdullah, A. (2012). Linguistik Umum. Jakarta: Erlangga.

Akmaluddin. (2016). Problematika Bahasa Indonesia Kekinian: Sebuah Analisis Kesalahan Berbahasa Indonesia Ragam Tulisan. Jurnal Mabasan,10 (2), 63-84.

Akmaluddin. (2018). Realitas Penggunaan Bahasa Indonesia Ragam Tulisan Pada Lembaga Pemerintahan. Jurnal Mabasan, 12 (1), 1-20.

Chaer, Abdul. (2013). Fonologi Bahasa Indonesia. Jakarta: PT Rineka Cipta.

Mahsun. (2012). Metode Penelitian Bahasa: Tahapan strategi metode dan tekniknya (Revisi). Jakarta: PT Raja Grafindo Persada.

Maisaroh, S.,Fajarianto, O., \& Nasir, M. (2019). Sistem Informasi Lowongan Kerja Kota Tangerang Berbasis Android dan Web 
Service. Jurnal Sisfotek Global, 9 (1), 112-117.

Ningrum, I.S.K., Purnami, L.E., \& Lestari, A. T. (2021). Analisis Kesalahan Berbahasa pada Unggahan Pamflet Media Sosial Instagram. Jurnal Lingua Rima, 10 (1), 99-103.

Nurdijan, S., Firman., \& Mirnawati (2018). Bahasa Indonesia untuk Perguruan Tinggi. Sulawesi Selatan: Aksara Timur.

Mantasiah \& Yusri. (2020). Analisis Kesalahan Berbahasa (Sebuah Pendekatan dalam Pengajaran Bahasa). Yogyakarta: Deepublish.

Ridho, Muhammad Rosyid. (2020). "Analisis Kesalahan Berbahasa Dalam Penulisan Surat Pemberitahuan Unit Kegiatan Mahasiswa di IAIN Surakarta Tahun 2019". Surakarta: Skripsi
IAIN Surakarta.

Setyawati, N. (2013). Analisis Kesalahan Berbahasa Indonesia: Yuma Pustaka.

Sikana, A. M., Nugroho, A. A., \& Tahe, P. (2021). Kesalahan Berbahasa Tataran Fonologi pada Pidato Juru Bicara Penanganan Virus Covid-19 Achmad Yurianto. Disastra: Jurnal Pendidikan Bahasa Dan Sastra Indonesia, 3 (1), 74-81.

Siyoto,Sandu. \&Sodik, Ali. (2015). Dasar Metodologi Penelitian. Yogyakarta: Literasi Media Publishing.

Sugono, D. (2009). Mahir Berbahasa Indonesia. Jakarta: PT Gramedia Pustaka Utama.

Sutabri, T. (2012). Analisis Sistem Informasi. Andi OFFSET. 